\title{
Kajian 'Urf pada Tradisi Rompak Paga Di Luhak Lima Puluh Kota Sumatera Barat
}

\author{
Salma \\ (Universitas Islam Negeri Imam Bonjol Padang, Jl. Prof. Mahmud Yunus Lubuk \\ Lintah Padang, Email: salmaalfaris1970@gmail.com) \\ Burhanuddin \\ (Universitas Islam Negeri Imam Bonjol Padang, Jl. Prof. Mahmud Yunus Lubuk \\ Lintah Padang, Email: burhanuddin045@gmail.com)
}

\begin{abstract}
Abstrak:
Masyarakat matrilineal Minangkabau adalah komunitas Muslim yang unik di Sumatera Barat. Islam yang kebanyakannya mengusung ide patrilineal bertemu/berhadapan dengan adat Minang yang mengusung ide matrilineal. Pada awal abad ke-19, para peneliti telah memprediksi bahwa komunitas masyarakat matrilineal Minangkabau akan mengalami perubahan mendasar dan bahkan ada yang mengatakan punah seiring perkembangan zaman. Setelah hampir satu abad berlalu, masyarakat matrilineal Minangkabau, meskipun mengalami perubahan dan pergeseran tetapi komunitas itu masih tetap ada di tengah masyarakat dalam tradisi-tradisi matriarkhal yang hidup dan terus berkembang seperti tradisi rompak paga di Luhak Lima Puluh Kota. Dalam tradisi ini, setiap laki-laki dari luar nagari atau luhak yang ingin menikahi perempuan di Luhak Lima Puluh Kota harus membayar sejumlah uang, emas atau benda berharga lain kepada ninik mamak perempuan atas nama adat. Pada satu sisi, adat rompak paga dilaksanakan untuk memelihara eksistensi kuasa/ kewenangan mamak terhadap kemenakan perempuannya di samping mengukuhkan identitas lelaki pendatang di dalam keluarga besar calon isterinya. Pada sisi lain, 'urf memandang rompak paga itu sebagai tradisi yang hidup dan tidak menyalahi ketentuan syari' at, logis, telah berlangsung sangat lama dan terus-menerus, serta dipraktekkan oleh umumnya masyarakat Luhak Lima Puluh Kota.
\end{abstract}

Kata Kunci:

Adat, Syari'at Islam, Minangkabau, Rompak Paga, 'Urf

al-Lhkam Vol.12 No.2 Desember 2017

DOI 10.19105/al-ihkam.v12i2.1458 


\begin{abstract}
:
The people of matriliny Minangkabau is an unique Muslim community in West Sumatera. Islam carrying the idea of patriliny is facing with Minangkabau custom carrying the idea of matriliny. In the earlier of 19 century, many researchers have predicted that the community of matriliny Minangkabau would be basically changed and even being extinct pass through the new era. More than ten decades passed away, the community of matriliny Minangkabau, although had been changing in several way but still going forward and keeping the traditions of matriarchal which are living and growing such as tradition of rompak paga in Luhak Lima Puluh Kota. In the tradition, every man who comes from out of the nagari or Luhak Lima Puluh Kota and wants to marry a woman in the Luhak has to pay some money, gold or other property to ninik mamak (leader of the clan) of the woman in the name of adat (custom). The tradition of rompak paga is applying to keep the existence of ninik mamak authority to his nieces, beside to strengthen the identity of outsider to the big family of the bride. On the other hand, 'urf appraised the tradition of rompak paga as a living tradition and not be in contradiction with Islamic sharia, logic and on going continually.
\end{abstract}

Keywords:

Custom, Islamic Sharia, Minangkabau, Rompak Paga, 'Urf

\title{
Pendahuluan
}

'Urf adalah salah satu dalil hukum (adillat al-ahkâm) atas suatu perbuatan yang tidak dijelaskan ketentuannya secara terperinci dalam al-Qur`an dan Sunnah. Berdasarkan hal itu, 'urf adalah metode atau cara yang ditempuh melalui ijtihad untuk menemukan hukum Islam dalam kebiasaan-kebiasaan yang telah dilakukan oleh masyarakat secara terus-menerus. Ketika ajaran Islam sudah semakin meluas, maka ajaran Islam dihadapkan pada beragam kebiasaan masyarakat yang sebelumnya tidak dikenal pada masa Nabi, sehingga diperlukan upaya sungguh-sungguh dari para ulama untuk mendudukkan hukumnya agar masyarakat bisa membedakan mana di antara kebiasaan itu yang dapat dilestarikan dan yang harus ditinggalkan. Kebiasaan masyarakat itu di antaranya berhubungan dengan perkawinan.

Aturan agama, negara, dan adat seringkali menyatu dalam tata penyelenggaraan perkawinan, termasuk di wilayah 
Minangkabau Sumatera Barat. Wilayah ini adalah salah satu provinsi di Indonesia dengan mayoritas penduduk yang beragama Islam. ${ }^{1}$ Menyatunya nilai agama, Negara, dan adat dalam perkawinan di Minangkabau membawa konsekuensi tersendiri. Apabila ada pelanggaran terhadap salah satu ketentuan adat maupun ketentuan agama Islam khususnya dalam masalah perkawinan, maka pelaku dan keluarganya akan menerima akibat dan sangsi seumur hidupnya dan berlanjut sampai pada anak keturunannya. Sangsi itu disebut dibuang sepanjang adat. ${ }^{2}$

Hukuman buang adat yang dijatuhkan masyarakat dulunya tidak tertulis namun di zaman modern telah ditetapkan dalam berbagai peraturan daerah dan peraturan nagari. ${ }^{3}$ Jenis hukuman adat

1 Minangkabau adalah suatu lingkungan adat di Provinsi Sumatera Barat dan sekitarnya. Pengertian Minangkabau tidak persis sama dengan pengertian Sumatera Barat. Hal ini disebabkan karena kata Minangkabau lebih banyak mengandung makna sosio-kultural, sedangkan kata Sumatera Barat lebih mengandung makna geografis administratif. Dengan demikian dapat dipahami bahwa, Minangkabau terletak dalam daerah geografis administratif Sumatera Barat dan juga menjangkau ke luar daerah Sumatera Barat yaitu ke sabagian barat daerah geografis administratif Provinsi Riau dan sebagian barat daerah geografis Provinsi Jambi. Kedua wilayah ini masuk ke dalam lingkungan sosio-kultural Minangkabau karena mereka secara sosial budaya pada umumya sama dengan masyarakat yang berada di Sumatera Barat. Lihat Helmy Panuh, Pengelolaan Tanah Ulayat Nagari pada Era Desentralisasi Pemerintahan di Sumatera Barat. (Jakarta: Rajawali Pers, 2012), 15.

2 Hukuman buang sepanjang adat telah dilaksanakan masyarakat Minangkabau sejak lama. Dalam dokumentasi Nagari Koto Gadang di Bukittinggi ditemukan Keputusan Kerapatan Nagari Koto Gadang Nomor 40 tanggal 23 April 1920 yang berisi tentang penetapan hukuman buang sepanjang adat. Dalam putusan itu disebut dengan istilah buang tikarang pada seorang perempuan Minang berinisial D yang kawin lari dengan laki-laki dari pulau Jawa berinisial P. Putusan buang tikarang itu menegaskan bahwa perempuan itu dikeluarkan sepanjang adat dalam Nagari Koto Gadang, keluar dari anak buah penghulu nan 24 suku di Koto Gadang, tidak sehina semulia, tidak sesakit sesenang, dan tidak seadat sepusaka dengan orang Koto Gadang lagi. Jika ada ninik mamak atau kaum keluarganya yang menerima D dengan baik ketika datang ke Koto Gadang, maka mereka turut dibuang sepanjang adat seperti yang diterima D. Lihat Chairul Anwar, Hukum Adat Indonesia Meninjau Hukum Adat Minangkabau. (Jakarta: Rineka Cipta, 1997), 147.

3 Sudah banyak daerah dan nagari yang menuliskan aturan-aturan adat ini ke dalam peraturan daerah atau peraturan nagari di antaranya adalah peraturan-peraturan adat di Kecamatan IV Angkek Canduang. Nagari-nagari di wilayah kecamatan ini telah menuliskan peraturan-peraturan adatnya termasuk peraturan dan sanksi pelanggaran perkawinan dalam beragam nama seperti Buek Taguah Ganggaman Arek 
ini bisa jauh lebih berat dari hukuman yang ditetapkan oleh negara/pengadilan. Oleh karena itu, masyarakat Minangkabau berupaya keras untuk memenuhi syarat-syarat perkawinan yang ditetapkan adat, walaupun banyak dari syarat itu memberatkan dan tidak diatur oleh agama.

Masyarakat Luhak Lima Puluh Kota memiliki tradisi tersendiri dalam penyelenggaraan perkawinan. Ada beberapa tahapan yang harus dilalui ketika akan dilangsungkan perkawinan. Pertama, pihak keluarga laki-laki melakukan kegiatan marosok yaitu datang berkunjung ke rumah keluarga perempuan untuk saling mengenal dan menemukan kesesuaian di antara kedua keluarga. Kedua, pihak keluarga laki-laki mengutus dubalang pegawai ${ }^{4}$ untuk meminang perempuan dengan membawa carano yang berisi siriah longkok. ${ }^{5}$ Ketiga, setelah keluarga perempuan menerimia siriah pinangan, maka mereka memanggil keluarga dekat utamanya niniak mamak (kepala suku) untuk bermusyawarah membicarakan pinangan dalam acara mangombang siriah. Dalam kegiatan magombang siriah ini dibicarakan banyak hal tentang pinangan yang datang mulai dari penjelasan tentang sosok dan kepribadian laki-laki yang meminang, asal usul daerahnya sampai pada kewajiban-kewajiban agama, negara dan adat yang harus dipenuhi oleh laki-laki yang meminang. Di antara kewajiban adat itu adalah memenuhi adat sasuduk. ${ }^{6}$

di Jorong Koto Hilalang, Buek Arek Satian Taguah di Jorong Tigo Jorong, dan Buek Arek Parik Putuih di Kenagarian Ampang Gadang.

4 Ada empat orang/jabatan di Minangkabau yang berfungsi sebagai pemimpin dengan hak dan kewajiban yang jelas dan terukur yaitu penghulu, manti, malim dan dubalang. Penghulu bertugas menghukum sepanjang adat (teguh pada adat), malim menghukum sepanjang syarak (teguh pada agama Islam), malim menghukum silang selisih (teguh dalam peradilan) dan dubalang menghukum ketika ada tumbuh perkelahian dan peperangan (teguh dalam urusan nagari). Lihat M. Nasroen, Dasar Falsafah Adat Minangkabau. (Jakarta: Pasaman, 1957), 134.

5 Siriah longkok adalah salah satu simbol yang digunakan dalam banyak kegiatan adat di Minangkabau. Biasanya siriah longkok ini terkumpul dalam wadah yang disebut uncang dan sekurang-kurangnya terdiri dari daun sirih yang tersusun rapi, kapur (sadah), gambir, pinang muda, tembakau. Keempat benda terakhir adalah pelengkap untuk memakan sirih. Lihat Amir M.S., Adat Minangkabau Pola dan Tujuan Hidup Orang Minang. (Jakarta: Mutiara Sumber Widya, 2003), 29.

6 Pimpinan Sembilan suku di Kecamatan Lampasi Tigo Nagari menjelaskan bahwa pembayaran biaya sasuduk digunakan pihak perempuan untuk membeli peralatan kamar seperti tempat tidur, kasur, selimut lemari, alas kasur (bed cover) dan pakaian 
Apabila perkawinan itu terjadi antara pasangan berbeda wilayah dan laki-laki berasal dari wilayah di luar nagari calon mempelai perempuan atau luar Luhak Lima Puluh Kota, maka pihak laki-laki dibebani kewajiban adat lain untuk membayar sejumlah uang/emas. Bayaran ini disebut dengan istilah rompak paga. Pembayaran rompak paga ini telah ditetapkan oleh pemegang kekuasaan adat yaitu ninik mamak (kepala suku). Uang ini dibayarkan bersamaan dengan pemberian sasuduk yang telah ditetapkan dalam kegiatan mangombang siriah (musyawarah pinangan). Besaran nilai uang rompak paga tidak sama antar keluarga. ${ }^{7}$ Jumlah ini bergantung kepada hasil musyawarah ninik mamak dan keluarga perempuan untuk menentukan besarannya. Dalam studi pendahuluan yang dilakukan pada bulan Desember 2016 diketahui bahwa tradisi rompak paga ini dan akibat pengabaiannya masih terjadi di Luhak.

Sejauh ini, belum ditemukan hasil penelitian tentang rompak paga di Luhak Lima Puluh Kota tetapi telah banyak hasil penelitan yang mengungkapkan sisi-sisi berbeda tentang adat Minangkabau. Para peneliti ranah Minangkabau lebih terfokus pada aspek yang lebih umum seperti pemerintahan nagari dan eksistensi matrilineal dalam menyongsong perubahan zaman. Adapun tradisi rompak paga merupakan salah satu tradisi yang ada dalam komunitas masyarakat Luhak Lima Puluh Kota yang notabene bagian dari wilayah matrilineal Minangkabau.

Persentuhan antara agama dan adat Minangkabau telah banyak didiskusikan dan diteliti oleh para peneliti baik para peneliti Indonesia maupun peneliti dari berbagai penjuru dunia. Ciri utama

mempelai perempuan sapatogak (sepatu, rok, baju dan jilbab). Besaran uang sasuduk bergantung pada hasil musyawarah ninik mamak keluarga perempuan dan kesanggupan calon mempelai laki-laki. Hal ini dijelaskan oleh Ir Datuak Tuluh, Ninik Mamak Suku Jambak (Pimpina Sembilan Suku) di Kecamatan Lampasi Tigo Nagari, wawancara, 26 Maret 2017.

7 Dalam studi pendahuluan pada bulan Desember tahun 2016 ditemukan beberapa pasangan yang menikah di Kota Payakumbuh dimana mempelai laki-laki berasal dari luar Luhak Lima Puluh Kota. Seorang mempelai laki-laki yang berasal dari Luhak Tanah Datar telah membayar uang rompak paga sebesar Rp. 600.000,- (enam ratus ribu rupiah) untuk perkawinannya dengan perempuan yang berasal dari Kecamatan Lampasi Tigo Nagari. Mempelai laki-laki lainnya berasal dari Luhak Agam membayar uang rompak paga sebesar Rp. 450.000,- (empat ratus lima puluh ribu rupiah) untuk perkawinannya deng perempuan dari Kecamatan Payakumbuh Timur. 
budaya Minangkabau adalah masyarakat muslim matrilineal terbesar di dunia. Hadler menegaskan bahwa penelitian tentang Minangkabau memperhatikan suatu pertentangan penting yang diungkapkannya dengan kata "pertikaian berdarah" antara adat dan Islam. ${ }^{8}$

Dalam review-nya, Chuzaifah mengatakan bahwa kedatangan Islam di Minangkabau yang sarat dengan nilai-nilai patriarchal, menjadi tandingan sistem matriarchy dalam etnik terbesar penganut Islam di Nusantara. ${ }^{9}$ Dalam adat Minangkabau, afiliasi utama seseoang adalah terhadap rumah gadang dan kampung suku atau klan maternal. Laki-laki menikah dengan anggota keluarga besar tetapi tetap terikat pada rumah ibu mereka. Mereka pulang ke rumah ibu mereka setiap hari untuk mengolah sawah ladang, memulihkan diri ketika sakit, dan akhirnya dimakamkan di perkuburan keluarga maternal. Seorang suami dan ayah adalah sosok yang datang dan pergi (diibaratkan seperti langau di ekor kerbau atau seperti abu di atas tunggul, angin kencang abu melayang). Menurut adat, mamak kepala suku (saudara lelaki ibu) menjadi otoritas laki-laki dalam kehidupan anak-anak.

Terjadinya perubahan dan pergeseran adat Minangkabau seperti yang diungkapkan oleh Syarifuddin ${ }^{10}$ di atas juga banyak dijelaskan oleh para peneliti lain. Hanya saja perdebatan ini terus berlangsung sampai saat ini dengan dua pilihan kesimpulan antara adat Minangkabau yang mengalami pergeseran di berbagai sisi substansi dengan adat Minangkabau yang berangsur punah dan tidak mampu bertahan dalam dunia modern. Ada di antara mereka yang memprediksi bahwa akan terjadi perubahan drastis dan kejatuhan adat Minangkabau seperti kekerabatan mamak-kemenakan (mother's brother-sister's children) sebagai inti matrilineal Minangkabau. Seperti diungkapkan oleh Evers, Schrieke menyebut prediksi kepunahan ini dengan istilah an agrarian revolution and a breakdown of communal

\footnotetext{
8 Jeffrey Hadler, Sengketa Tiada Putus: Matriarkat, Reformisme Islam, dan Kolonialisme di Minangkabau, Judul asli: Muslim and Matriarchs: Cultural Resilience in Indonesia Through Jihad and Colonialism, Penerjemah, Samsudin Berlian. (Jakarta: Freedom Institute, 2010), 3.

9 Yuniyanti Chuzaifah, "Dekonstruksi Makna Kuasa dalam Matriarchy", Studia Islamika, Vol. 9, Nomor 2. 2002, 172.

10 Amir Syarifuddin, Pelaksanaan Hukum Kewarisan Islam dalam Lingkungan Adat Minangkabau, (Jakarta: Gunung Agung, 1984), 332.
} 
landownership (1960), Muhammad Yamin dengan ungkapan revolution of adat Minang (1952), Sa'danoer dengan ungkapan the communal matrilineal system of inheritance is fading away (1971).

Menanggapi prediksi para peneliti itu, Evers mengatakan adat Minangkabau masih kuat. Terdapat setidaknya tiga aspek yang membuat adat Minangkabau dapat tetap bertahan. Pertama, penyelesaian konflik adat dan agama Islam. Taufik Abdullah menjawab bagaimana masyarakat Minangkabau menjembatani paradoks yang ada. Dia menjelaskan bagaimana matriarchy bisa bertahan karena kemampuan Minangkabau dalam mensintesiskan kontradiksi tersebut secara harmonis. ${ }^{11} \mathrm{Kedua}$, merantau (the system of voluntary migration). Ketiga, pemilikan harta pusaka secara bersamasama (the communal ownership of land). ${ }^{12}$

Harta pusaka tidak dimiliki secara perorangan. Kadangkadang harta pusaka dikelola secara bersama antara penghulu dan kemenakan dan hasilnya dibagi bersama. Situasi ini dikenal dengan ungkapan pasiduoan (dibagi dua) di beberapa wilayah nagari di Minangkabau dan isi adat di nagari lainnya. ${ }^{13}$ Di sisi lain, kaum perempuan tetap memelihara rumah pusaka dan menjaga harta pusaka serta tradisi Minangkabau lainnya. Pada zaman sekarang (mulai tahun 80an), perempuan Minang juga pergi merantau, untuk meneruskan pendidikan, bekerja atau ikut suami. Perantau urban ini tetap dekat dengan keluarga di kampungnya. Baik di kota atau desa, mereka yang telah terhimpun dalam nuclear family ini tetap menjalankan fungsinya sebagai keluarga besar (extended family). Pola ini meningkat secara signifikan dan membantu ketahanan adaptasi matrilineal Minangkabau dalam dunia modern. ${ }^{14}$

Berdasarkan latar belakang yang dikemukakan di atas, maka fokus penelitian ini adalah: pertama, apakah makna tradisi rompak paga dalam komunitas adat masyarakat Luhak Lima Puluh kota; kedua, bagaimanakah latar belakang dan tujuan pembayaran rompak paga

\footnotetext{
11 Yuniyanti Chuzaifah, "Dekonstruksi..., 172.

12 Hans Dieter Evers, "Changing Patterns of Minangkabau Urban Land-Ownership", Bijdragen tot de Taal, Vol. 131, Nomor 1. (1975), 87.

13 J.S.Kahn, "Traditio, Matriliny and Change among the Minangkabau of Indonesia", Bijdragen tot de Taal, Vol. 132, No. 1. (1976), 87-88.

14 Nancy Makepiece Tanner, “The Nuclear Family in Minangkabau Matriliny: The Mirror of Disputes", Bijdragen tot de Taal, Vol. 138, No.1. (1982), 130.
} 
dalam perkawinan di Luhak Lima Puluh Kota; ketiga, apakah akibat hukum keengganan pembayaran rompak paga; keempat, adakah nilainilai 'urf dalam tradisi rompak paga di Luhak Lima Puluh Kota.

\section{Metode Penelitian}

Jenis penelitian adalah penelitian lapangan dengan pendekatan kualitatif. Data yang digunakan adalah data primer dan sekunder. Pengumpulan data dilakukan dengan cara observasi prosesi penetapan rompak paga, wawancara dengan ninik mamak, ibu calon mempelai perempuan, (saudara laki-laki dari ibu calon pengantin perempuan), calon pengantin laki-laki dan perempuan, Ketua KUA dan lain-lain serta studi dokumentasi. Data yang diperoleh dianalisis dengan menggunakan teknik reduksi, pemaparan data dan penarikan kesimpulan.

\section{Kajian Teori}

\section{‘Urf dan Adat dalam Perkawinan}

'Urf merupakan salah satu cara atau metode yang dirumuskan oleh ahli ushul fikih untuk menetapkan dalil hukum satu kebiasaan masyarakat. 'Urf menjadi kebiasaan mayoritas umat dalam penilaian suatu perkataan atau perbuatan. Berdasarkan hal itu, maka 'urf itu bisa dalam bentuk perbuatan dan bisa juga dalam bentuk perkataan, bersifat umum atau khusus dan bisa juga berbentuk shahîh atau fâsid. ${ }^{15}$ Pembagian dari sisi perkataan dan perbuatan bisa juga berbentuk 'urf shahîh dan fâsid.

'Urf shahîh merupakan kebiasaan masyarakat yang tidak bertentangan dengan al-Qur`an dan Sunnah, mengandung kebaikan dan tidak memberi kemudaratan seperti kebiasaan masyarakat menjamu orang-orang yang telah selesai shalat idul fitri. Sebaliknya, 'urffâsid merupakan kebiasaan masyarakat yang bertentangan dengan nash al-Qur`an dan Sunnah, mengandung kemudaratan, dan tidak memberi kebaikan seperti kebiasaan banyak orang berpakaian yang tidak menutupi auratnya. ${ }^{16}$

\footnotetext{
15 Wahbah al-Zuhaylî, Ushûl al-Fiqh al-Islâmî, Jilid II. (Beirût: Dâr al-Fikr, 1986), 828829.

16 Ali Hasbullah, Ushûl al-Tasyrî' al-Islâmî, (Mesir: Dâr al-Ma'ârif, 1971), 311.
} 
'Urf dipandang shahîh ketika kebiasaan masyarakat itu tidak menghalalkan hal-hal yang diharamkan dan tidak mengharamkan hal-hal yang dihalalkan seperti penentuan mahar yang ditunaikan sebelum akad perkawinan dan mahar yang diangsur pembayarannya. Sementara itu 'urf fâsid merupakan kebiasaan masyarakat yang menghalalkan hal-hal yang diharamkan dan mengharamkan hal-hal yang dihalalkan seperti kebiasaan orang mengkonsumsi khamr secara terbuka, melakukan aktivitas riba dan lain-lain.

Sebagian ulama ushul fikih mengatakan bahwa 'urf adalah salah satu dalil penetapan hukum syara'. Pandangan ini berdasar atas Q.S al-A'raf (7): 199. Pendapat di atas juga berdasar pada ungkapan Ibnu Mas'ud bahwa sesuatu yang dpandang baik oleh orang Islam maka hal itu baik di sisi Allah dan sesuatu yang dipandang buruk oleh orang Islam maka hal itu juga buruk di sisi Allah. ${ }^{17}$ Ayat di atas bisa dijadikan dalil oleh ulama ushul karena lafal العرف dalam ayat di atas menurut bahasa artinya adalah hal-hal baik yang dikerjakan berulang dan terus-menerus.

Dalam ungkapan Ibnu Mas'ud dijelaskan bahwa jika suatu perbuatan dipandang baik oleh umat Islam, maka perbuatan itu bisa menjadi satu hukum yang dipatuhi. Ulama Hanafiah dan Malikiyah mengatakan bahwa 'urf bisa menjadi dalil untuk menetapkan hukum syarak dan kebiasaan-kebiasaan baik itu pada akhirnya menjadi hukum (العادة المحكمة) yang terungkap dalam penjelasannya bahwa proses pembentukan 'urf menempati tempat syarat dalam akad-akad dalam kaidahnya 19 dengan makna sesuatu yang telah tetap karena 'urf maka hal itu seperti ditetapkan berdasarkan nash al-Qur'an dan Sunnah. Ulama lain mengatakan bahwa segala sesuatu yang tidak ditentukan dalam al-Qur'an dan Sunnah, tidak dijelaskan dalam dalil-dalil lain dan tidak juga dalam ungkapan bahasa, maka hal itu dikembalikan pada ' $u r f .{ }^{20}$

\footnotetext{
17 Al-Sarakhsî, Kitâb al-Mabsûth, Juz XII. (Beirût: Dâr al-Fikr, 1999), 138.

18 Ibnu Qayyim al-Jawziyyah, I'lâm al-Muwaqi'în, Jilid II. (Kairo: Dâr al-‘Urûbah, 1998), 89.

${ }^{19}$ Sekelompok Syafi'iyah berbeda pandangan dengan kaidah ini. Mereka mengatakan bahwa hal itu tidak bisa menjadi syarat. Lihat al-Suyûthî, al-Asybâh wa al-Nazhâir. (Beirût: Dâr al-Fikr, 1989), 86.

${ }^{20}$ Al-Syâthibî, al-I'tishâm. (Beirût: Dâr al-Fikr, 2007), 62.
} 
Misalnya 'urf (kebiasaan masyarakat) menentukan ukuran terpelihara (الحرز) pada harta yang dicuri. Ulama ushul fiqh membedakan antara 'urf dan adat dalam membahas kedudukannya sebagai salah satu dalil penetapan hukum syara'. Di antara mereka ada yang mengatakan bahwa adat merupakan kebiasaan terusmenerus yang dilakukan oleh setiap orang khusus untuk dirinya sendiri. Ketika kebiasaan itu dilakukan oleh orang banyak maka hal ini disebut 'urf.

\section{Mahar dalam Perkawinan}

Di antara kewajiban suami terhadap isterinya adalah memberikan materi berupa mahar, nafkah, dan tempat tinggal dan sesuatu yang bersifat immateri seperti keadilan, perlakuan baik dan penuh hormat. Pemberian yang bersifat materi ini terdiri dari tiga bagian yaitu pemberian sebelum/ketika akad perkawinan, pemberian dalam perkawinan, dan pemberian ketika terjadi perceraian. Pemberian sebelum akad perkawinan dikenal dengan istilah mahar. Mahar adalah harta yang menjadi hak isteri karena akad perkawinan atau karena telah terjadi hubungan seksual. Tujuan pemberian mahar ini adalah untuk menghalalkan hubungan biologis. ${ }^{21}$ Kewajiban untuk membayar mahar ini didasarkan kepada Q.S al-Nisa` (4): 4, 2425. Menurut ahli hukum Islam, mahar tidak termasuk rukun dan tidak juga syarat dalam perkawinan tetapi mahar adalah akibat yang ditimbulkan karena adanya perkawinan.22

Batas minimal kuantitas sebuah mahar senilai dengan nisab potong tangan dan cincin besi merupakan batas minimal nilai mahar yang disegerakan. ${ }^{23}$ Pada masyarakat Muslim Suku Dani di Papua, babi digunakan sebagai mahar untuk syarat perkawinan. ${ }^{24}$ Di wilayah Batak Toba, mahar disebut sinamot yang terdiri dari uang, benda

21 Muhammad Khatîb al-Syarbinî, Mughni al-Muhtâj, Jilid III. (Beirût: Dâr al- Fikr, 1997), 220.

22 al-Fairuzzabadi al-Syirâzî, al-Muhazzab, Jilid II. (Beirût: Muassasah al-Risâlah, 1989), 55.

23 al-Syawkânî, Nayl al-Awthâr, Jilid VI. (Kairo: Dâr al-Hadîs, 2010), 168Bambang Sugianto, "Kualitas dan Kuantitas Mahar dalam Perkawinan (Kasus Wanita yang Menyerahkan Diri kepada Nabi SAW," Asy-Syir'ah Jurnal Ilmu Syari'ah dan Hukum, Volume 45, Nomor II. (Juli-Desember 2011), 1357.

24 Umar Yelepele dan Moh. Hefni, "Perkawinan Adat Muslim Suku Dani di Papua, alIhkam, Vol. 7, No.1, Juni 2012, 17. 
berharga dan kekayaan lainnya dengan makna mengganti kerelaannya keluar dari marga ayahnya menuju marga calon suaminya. ${ }^{25}$

Di wilayah Bugis, pemberian mahar disebut dengan sompa mahar yaitu dalam bentuk perhiasan dengan ukuran kati atau ringgit dan ditambah dengan belanja pesta. Di wilayah Bugis yang berbeda biasanya pihak perempuan meminta sompa mahar dalam bentuk sebidang tanah. ${ }^{26}$ Masyarakat di wilayah Bantaeng Sulawesi Selatan menjadikan lahan budidaya rumput laut sebagai mahar dalam perkawinan. ${ }^{27}$

Masyarakat muslim suku Sasak di kelurahan Ampenan Tengah melaksanakan adat pisuka yang jauh lebih kompleks daripada mahar. Pisuka mempunyai kekuatan yang bisa saja memperberat jalannya perkawinan, serta menunda terlaksananya akad nikah. Sementara pisuka tidak dikenal di dalam Islam. Kewajiban dari calon suami kepada calon isterinya hanyalah berupa mahar. Pemberian pisuka yang hanya merupakan kepantasan adat tidak mempunyai kekuatan dan akibat hukum untuk membuat suatu proses akad perkawinan rumit dan tertunda, karena pisuka tidak dikenal dalam Islam serta praktik pisuka yang terjadi di kelurahan Ampenan Tengah tidak sesuai dengan ketentuan hukum Islam. ${ }^{28}$ Dari beberapa contoh di atas dapat disimpulkan bahwa bentuk, ukuran dan nilai mahar memang berbeda-beda di setiap komunitas masyarakat Indonesia.

Misalnya masyarakat Kelurahan Untia Kecamatan Biringkanaya menganggap bahwa uang panaik adalah sejumlah uang yang wajib diberikan oleh calon suami kepada pihak keluarga calon istri. Uang panaik digunakan sebagai biaya dalam resepsi perkawinan. Tujuan pemberian uang panaik adalah untuk menghargai atau

25 Jhonson Pardosi, "Makna Simbolik Umpasa, Sinamot dan Ulos Pada Adat Perkawinan Batak Toba," Logat Jurnal Ilmiah Bahasa dan Sastra, Volume IV, Nomor 2. (Oktober 2008), 105.

26 Ismail Suardi Wekke, "Islam dan Adat dalam Pernikahan Masyarakat Bugis di Papua Barat," Thaqafiyyat, Volume 13, No. 2, (Desember 2012), 317.

27 Sri Susyanti Nur dan Abrar Saleng, "Aspek Sosioyuridis Lahan Budidaya Rumput Laut Sebagai Mahar Perkawinan di Kabupaten Bantaeng Sulawesi Selatan," Prosiding Akuakultur Indonesia, (2013), 343.

${ }_{28}$ Ulfa Ufi Azmi, “Tinjauan Hukum Islam Terhadap Praktik Pisuka Pada Perkawinan Adat Masyarakat Muslim Suku Sasak Di Kelurahan Ampenan Tengah Lombok Barat, Thesis. (UIN Sunan Kalijaga, 2012) 
menghormati perempuan yang ingin dinikahinya dengan memberikan pesta yang megah untuk pernikahannya melalui uang panaik tersebut. Kedudukan uang panaik dalam perkawinan adat tersebut adalah sebagai salah satu pra syarat, karena jika tidak ada uang panaik maka tidak ada perkawinan. Pemberian uang panaik dalam perkawinan adat Bugis Makassar di wilayah ini tidak diatur dalam hukum Islam. Hukum Islam hanya mewajibkan calon mempelai laki laki membayarkan mahar kepada calon mempelai perempuan dan itupun dianjurkan kepada pihak perempuan agar tidak meminta mahar berlebihan. ${ }^{29}$

Masyarakat Desa Legok melakukan tradisi pembayaran uang pelangkah perkawinan. Adat tradisi pembayaran uang pelangkah dapat dilestarikan karena adat tradisi pembayaran uang pelangkah ini sebagai simbol identitas suatu daerah, dan dapat juga sebagai suatu bentuk penghormatan kepada kakak yang akan dilangkahi dan sebagai penjaga hubungan baik keluarga. ${ }^{30}$ Adat ini menjadi jalan keluar bagi seorang adik yang mendahului kakak perempuannya untuk menikah.

\section{Hasil Penelitian}

\section{Demografi Luhak Lima Puluh Kota}

Sumatera Barat terdiri dari beberapa kabupaten dan kota di antaranya adalah Kabupaten Lima Puluh Kota. Kabupaten Lima Puluh Kota pada dasarnya adalah Luhak Lima Puluh Kota sebagai wilayah asli Minangkabau yang terpecah menjadi Kota Payakumbuh dan Kabupaten Lima Puluh Kota. Wilayah ini berjarak lebih kurang $130 \mathrm{~km}$ dari Kota Padang, ibukota Provinsi Sumatera Barat dan bisa dicapai dalam waktu 3.5 jam perjalanan darat. Kabupaten Lima Puluh Kota memiliki tradisi yang berbeda dalam penyelenggaraan perkawinan dengan luhak dan rantau Minangkabau lainnya. ${ }^{31}$

\footnotetext{
${ }^{29}$ Moh. Iqbal, “Tinjauan Hukum Islam Tentang Uang Panaik (Uang Belanja) Dalam Perkawinan Adat Suku Bugis Makassar Kelurahan Untia Kecamatan Biringkanaya Kota Makassar," Thesis. (UIN Sunan Ampel Surabaya, 2012).

30 Muhammad Ilman, "Tradisi Pembayaran Uang Pelangkah dalam Perkawinan (Studi Kasus di Desa Legok, Kecamatan Legok Kabupaten Tangerang," Skripsi. (UIN Jakarta, 2016).

31 Rantau Minangkabau adalah wilayah luar Luhak Nan Tigo. Asal atau sejarah terbentuknya rantau adalah dengan melihat hukum-hukum adat yang berlaku di
} 
Tidak ditemukan perbedaan pendapat tentang fakta bahwa Luhak Nan Tigo adalah inti dari tanah Minangkabau. Awalnya dari taratak yang berkembang menjadi dusun, dusun menjadi nagari, nagari berkembang jadi koto (kota) dan koto menjadi Luhak. Daerah seputar gunung Marapi, Singgalang, Tandikat, dan Sago di darat kemudian dibagi menjadi Tiga Luhak: Luhak Tanah Datar, luhak tertua (sekitar Batusangkar), Luhak Agam, yang di tengah (sekitar Bukittinggi), dan Luhak Limapuluh Kota, yang termuda (sekitar Payakumbuh). Semuanya disebut dengan Luhak Nan Tigo atau Darek (darat). ${ }^{32}$ Luhak Lima Puluh Kota adalah luhak termuda di antara dua luhak (Luhak Tanah Datar dan Luhak Agam) yang lain. Secara administratif Luhak Lima Puluh Kota Kota terdiri dari dua daerah tingkat dua yaitu Kabupaten Lima Puluh Kota dan Kota Payakumbuh. Kota Payakumbuh sendiri terletak di tengah-tengah wilayah Kabupaten Lima Puluh Kota.

Sejarah Kabupaten Lima Puluh Kota tidak bisa dilepaskan dari sejarah Minangkabau. Wilayah inti Minangkabau yang dikenal sebagai Luhak Nan Tigo salah satunya adalah Luhak Lima Puluh Kota yang dikenal juga dengan nama Luhak Nan Bungsu. Sejarah mencatat pada zaman Paderi33 secara administratif Kabupaten Lima Puluh Kota

tengah masyarakat yaitu organisasi sosial, sistem kekerabatan, hukum perkawinan, harta pusaka dan tanah dan sebagainya. Sekalipun hukum-hukum adat tersebut telah mengalami perubahan di rantau tetapi masih keras berbau Minangkabau. C. Van Vollenhoven mengemukakan dalam Het Adatrecht van Ned. Indie, Jilid I, 246-272 seperti yang dikutip oleh Mochtar Naim bahwa rantau-rantau yang termasuk ke dalam wilayah hukum (rechtskring) Minangkabau adalah wilayah Siak, Kampar, Kuantan Indragiri, Tembesi Ulu/Jambi, Muko-muko, Kerinci, Natal, Barus, Singkel, Tapak Tuan, Meulaboh, Naning (Melaka), Negeri Sembilan, Sebagian Kedah dan Madagaskar. Lihat Mochtar Naim, Merantau Pola Migrasi Suku Minangkabau. (Jakarta: Rajawali Pers, 2013), 369.

32 Mochtar Naim, Merantau..., 65.

33 Gerakan Padri adalah salah satu bentuk persentuhan terbesar antara adat Minangkabau (matriarkat) dengan syariat Islam. Gerakan Padri adalah satu gerakan yang berupaya untuk mengembalikan dan memurnikan ajaran Islam di wilayah Minangkabau sesuai dengan pedoman dasar dalam al-Qur`an dan Sunnah. Gerakan ini diusung dan dikembangkan oleh orang-orang (utamanya ulama) yang bersemangat tinggi memajukan agama Islam utamanya setelah kepulangan tiga orang haji dari Mekah yaitu Haji Miskin, Haji Sumanik dan Haji Piobang. Pimpinan gerakan padri ini dikenal dengan istilah harimau nan salapan. Oleh karena itu gerakan ini sering bertentangan dengan kaum adat Minangkabau dan penjajah Belanda. Gerakan ini sangat mengemuka ketika dipimpin oleh Tuanku Imam Bonjol. Perang 
masih berdasarkan persekutuan hukum adat yang terdiri dari limo puluah koto (50 kota). ${ }^{34}$ Wilayah limo puluah koto ini berkembang menjadi lima puluh nagari adat. Kabupaten ini terletak antara $0025^{\circ} 28,71$ LU dan $0022^{\circ} 14,52$ LS serta antara $100015^{\circ} 44,10$ $100050^{\circ} 47,80$ BT. Kabupaten ini juga diapit oleh empat kabupaten dan satu propinsi yaitu Kabupaten Agama, Kabupaten Tanah Datar, Kabupaten Sijunjung, Kabupaten Pasaman dan Provinsi Riau. ${ }^{35}$

Jumlah penduduk Kabupaten Lima Puluh Kota pada tahun 2015 sebanyak 368.985 jiwa. ${ }^{36}$ Agama yang dianut masyarakat sesuai data tahun 2012 adalah agama Islam, Kristen Katolik dan Protestan dengan perbandingan 337.266 jiwa beragama Islam, 90 jiwa beragama Katolik dan 136 jiwa beragama Kristen Protestan. Etnis masyarakat didominasi oleh suku Minangkabau, sedangkan Jawa dan Batak menjadi etnis minoritas. Ketiga etnis ini hidup secara berdampingan dengan aman dan damai. Kabupaten Lima Puluh Kota terdiri dari 13 kecamatan, 79 nagari dan 401 jorong. Luhak Lima Puluh Kota secara adat diungkapkan dengan pepatah buminyo sajuak, aianyo janiah, ikannyo jinak. Artinya, meskipun masyarakatnya homogen tetapi penuh dengan suasana kerukunan serta memiliki ketenangan dalam berfikir. ${ }^{37}$

Padri berlangsung dari tahun 1821-1837. Ada juga yang menyebutkan bahwa perang ini berlangsung pada tahun 1803-1838. Gerakan ini dikenal juga dengan istilah Pedir, Pideri dan Pidari yang diambil dari nama tempat di pesisir Barat Sumatera. Tempat itu dulunya menjadi lokasi keberangkatan jemaah haji. Lebih jauh lihat Rusli Amran, Sumatera Barat Hingga Plakat Panjang. (Jakarta: Sinar Harapan, 1985), 385.

34 Menurut tambo kata limo puluah kota diambil dari peristiwa kedatangan lima puluh rombongan yang datang dari Pariangan Padang Panjang untuk mencari pemukiman baru di kaki Gunung Sago. Dalam perjalanan, rombongan itu menemukan sebuah padang ribu-ribu yang luas di sekitar Piladang dan Situjuh dan mereka memutuskan untuk bermalam di daerah itu. Pada hari-hari selanjutnya rombongan ini terpisahpisah menuju berbagai wilayah di Kabupaten Lima Puluh Kota dan setiap tempat yang mereka singgahi diberi nama sesuai dengan keadaan ketika bertemu atau berpisah dengan rombongan asalnya. Lihat Sutan M. Taufiq (red.), Direktori Minangkabau 2012. (Batusangkar: Badan Pekerja Pucuak Adat Alam Minangkabau (BP-PAAM) Istano Silinduang Bulan Pagaruyuang-Batusangkar dan Lembaga Kerapatan Adat Alam Minangkabau (LKAAM) Provinsi Sumatera Barat, 2012), 977.

35 Badan Pusat Statistik, Kabupaten Lima Puluh Kota Dalam Angka Tahun 2016.

36 Ibid., 53.

37 Sutan M. Taufiq (red.), Direktori..., 977. 
Adapun Kota Payakumbuh juga tidak bisa dipisahkan dari sejarah limo puluah koto sebagai persekutuan hukum dalam masyarakat Minangkabau. ${ }^{38}$ Wilayah ini terdiri dari 5 kecamatan, 76 kelurahan, 8 nagari dan 73 jorong. Secara geografis Kota Payakumbuh terletak pada posisi $00^{\circ} 10$ sampai dengan $00^{\circ} 17$ LS dan $100^{\circ} 35$ sampai dengan 100 45 BT. ${ }^{39}$ Pada tahun 2014 jumlah penduduk Kota Payakumbuh 125.690 jiwa. ${ }^{40}$

\section{Makna Rompak Paga dalam Komunitas Adat Masyarakat Luhak Lima Puluh Kota}

Dalam bahasa Minangkabau, rompak paga terdiri dari dua kata yaitu rompak dan paga. Dalam Kamus bahasa Indonesia, kata rompak memiliki makna merampok atau menyamun di laut tetapi ada juga dengan makna merobohkan atau merusakkan. ${ }^{41}$ Sedangkan kata paga bermakna pagar dalam bahasa Indonesia. Ketika kedua kata ini digabungkan maka dapat dimaknai sebagai satu tindakan merusak atau merobohkan pagar. Tradisi rompak paga yang dimaksud oleh masyarakat Luhak Lima Puluh Kota sepertinya mengacu pada kedua makna terakhir ini sebagai kiasan dari tindakan seseorang yang memasuki wilayah orang lain dengan cara yang lebih sulit (melompat) untuk mendapatkan/mengawini perempuan yang berada dalam wilayah yang dimasukinya. Secara mendasar, perkawinan di Luhak Lima Puluh Kota dilaksanakan sesuai dengan ajaran (syari'at) Islam dan aturan-aturan negara tetapi dalam

\footnotetext{
38 Masyarakat Luhak Lima Puluh Kota hidup dalam susunan kemasyarakatan yang berbentuk persekutuan-persekutuan dalam suasana hukum adat. Persekutuanpersekutuan hukum adat ini terhimpun dalam nagari-nagari dengan anggota kesatuan yang saling terikat dan terhubung erat. Dalam upaya memenuhi kebutuhan dan kepentingan persekutuan hukum tersebut selalu dijumpai orang-orang yang berkuasa dan bertindak atas nama persekutuan itu. Unsur pengikat anggota persekutuan terdiri dari unsur teritorial (wilayah) dan unsur genealogi (pertalian darah yang mengikat suku hanyalah pertalian darah menurut garis ibu). Oleh karena itu, satu nagari adalah persekutuan hukum yang tersusun berdasarkan faktor genealogi dan faktor teritorial. Lihat Chairul Anwar, Hukum..., 7-9.

39 Badan Pusat Statistik, Payakumbuh Dalam Angka. (Payakumbuh: BPS Kota Payakumbuh, 2015), 3.

40 Ibid., 63.

41 Departemen Pendidikan Nasional, Kamus..., h. 1181.
} 
pelaksanaannya tidak bisa dilepaskan dari tradisi masyarakat yang sudah ada sejak lama.

Oleh karena itu, dalam pelaksanaan tradisi rompak paga ini terlihat kekuasaaan dan hubungan yang masih terjaga kuat antara saudara laki-laki ibu (mamak) dengan ibu dan anak perempuannya (extended family). Para pemuka adat mengatakan bahwa tradisi rompak paga adalah sejumlah uang atau benda lain (emas dan semen) yang harus dikeluarkan oleh seorang calon pengantin laki-laki yang berasal dari luar wilayah adat calon pengantin perempuan dan diserahkan kepada nagari atau ninik mamak calon pengantin perempuan.42 Luar wilayah adat calon pengantin perempuan mencakup wilayah terdekat yaitu luar dari nagari tempat tinggal perempuan dan wilayah yang lebih jauh yaitu luar luhak Lima Puluh Kota baik antara kota/kabupaten, provinsi maupun luar negeri (warga negara asing). ${ }^{43}$

Pada umumnya nagari-nagari di Luhak Lima Puluh Kota menerapkan pembayaran rompak paga tetapi dengan nama yang agak berbeda. Kata rompak paga diucapkan oleh masyarakat yang berasal dari Nagari Lampasi dan sekitarnya.44 Masyarakat Nagari Situjuah menyebut ungkapan rompak paga dengan nama lompek paga ${ }^{45}$ dan masyarakat Nagari Tujuah Koto Talago Kecamatan Guguak serta nagari di sekitarnya menyebut/mengucapkannya dengan istilah lompek page dan dalam beberapa peraturan nagari ditulis dengan istilah rompak paga. ${ }^{46}$ Kata ini dituangkan dalam peraturan nagari tetapi disebut dengan bahasa asli dalam komunikasi sehari-hari.

Semua ungkapan tersebut memiliki makna yang sama sekalipun dengan dialek yang berbeda dan beberapa nagari menerjemahkannya ke dalam bahasa Indonesia dengan istilah lompat pagar. Dalam hal ini dapat disimpulkan bahwa tradisi rompak paga memiliki makna yang menggambarkan usaha keras seorang laki-laki

42 Yuhar Datuak Gindo Rajo Nan Sati, Ninik Mamak Suku Picancang Suku Sambilan, wawancara, (Lamposi, 12 Agustus 2017).

43 Datuak Tan Marajo, Datuak Don Vesky, dan Datuak Sayiah Malano, Ninik Mamak beberapa suku di Nagari Situjuah Batua, wawancara, (23 Juli 2017).

44 Z.A. Datuak Tuluh, Pamuncak Adat Suku Ompek Niniak Sungai Durian, wawancara, (12 Agustus 2017)

45 Datuak Darius, Ninik Mamak suku di Nagari Situjuah Batua, wawancara, (23 Juli 2017)

46 Perubahan Peraturan Nagari Guguak VII Koto Talago Nomor 3 Tahun 2015 Tentang Iuaran Jasa Pelayanan Administrasi Pasal 1. 
untuk mengawini seorang perempuan dengan cara memenuhi syaratsyarat adat yang ditetapkan kepala suku, sehingga tidak mudah baginya untuk mendapatkan perempuan tersebut. Usahanya ini dikiaskan pada kata rompak paga atau merobohkan/meruntuhkan pagar untuk dapat masuk dan tidak masuk dengan mudah melalui sebuah pintu.

Dalam konteks kekinian, rompak paga telah dicantumkan dalam sebuah peraturan nagari yang semakin mengukuhkan pelaksanaannya. Upaya pemuka adat untuk mencantumkan tradisi rompak paga dalam peraturan-peraturan nagari adalah sebagai upaya memelihara tradisi dan adat Minangkabau yang berangsur hilang. Upaya ini disambut baik oleh pemerintah daerah Kabupaten Lima Puluh Kota dan Kota Payakumbuh. Dukungan pemerintah daerah ini terlihat pada legalisasi dokumen-dokumen peraturan nagari yang salah satu isinya menetapkan aturan pembayaran rompak paga. Dalam beberapa peraturan adat salingka (sekitar) nagari yang telah dilegalisasi oleh pemerintah daerah disebutkan:

Biaya administrasi dan uang adat adalah biaya yang dipungut oleh ninik mamak (petinggi adat) terhadap anak kemenakannya yang akan melangsungkan pernikahan. Terhadap sumando (laki-laki yang berasal dari luar Nagari Sungai Beringin) dipungut biaya lompat pagar sebesar Rp.500.000.- (lima ratus ribu rupiah) belum termasuk biaya untuk perempuan. ${ }^{47}$ Dalam Keputusan KAN Nagari Batu Balang Kecamatan Harau Kabupaten Lima Puluh Kota ditetapkan besaran uang rompak paga sebanyak RP. 250.000,- (dua ratus lima puluh ribu rupiah). ${ }^{48}$ Dalam Peraturan Nagari Durian Godang Kecamatan Payakumbuh ditetapkan emas senilai 1,5 mas (lebih kurang 3.75 gram mas) untuk bayaran rompak paga. ${ }^{49}$

Berdasarkan pengertian yang dituangkan dalam peraturan nagari di atas dipahami bahwa rompak paga adalah uang adat yang diambil oleh ninik mamak dari calon suami kemenakan perempuannya yang berasal dari luar nagari untuk dan atas nama adat.

47 Peraturan Adat Salingka Nagari Di Lingkungan Kerapatan Adat Nagari (KAN) Kenagarian Sungai Baringin Kecamatan Payakumbuh Kabupaten Lima Puluh Kota Pasal 4 dan 5.

48 Berita Acara Rapat Koordinasi antara Pemerintahan Nagari dengan Kerapatan Adat Nagari (KAN) Nagari Batu Balang Tanggal 03 Februari 2015.

49 Peraturan Nagari Durian Gadang Nomor 04 Tahun 2009 Tentang Pungutan Nagari Pasal 21. Hal ini dikuatkan oleh Datuak Ghambai, Niniak Mamak suku di Nagari Durian Godang, wawancara, (23 Juli 2017). 


\section{Latar Belakang dan Tujuan Pembayaran Rompak Paga}

Pada dasarnya setiap ninik mamak yang diwawancarai di beberapa nagari/wilayah Luhak Lima Puluh Kota tidak mengetahui secara pasti latar belakang sejarah adanya bayaran rompak paga. Secara umum mereka mengatakan bahwa ketika mereka diangkat menjadi penghulu, mereka telah mendapati adanya ketentuan pembayaran rompak paga ini dengan tidak mengetahui asal-usulnya. Hanya saja mereka mengatakan bahwa dulunya (lebih kurang dua dekade sebelumnya) rompak paga ini dibayar dengan benda-benda tertentu seperti emas di sebagian besar wilayah Lima Puluh Kota di antaranya wilayah Kecamatan Payakumbuh, Kecamatan Akabiluru, Taram, Situjuah serta semen, batu bata dan atap seng di wilayah Kecamatan Lampasi Tigo Nagari. ${ }^{50}$ Di nagari tertentu, emas dicantumkan dalam peraturan nagari sebagai alat ukur rompak paga tetapi ditunaikan/dibayarkan dengan uang. ${ }^{51}$ Menururt para ninik mamak, pembayaran dengan uang lebih mudah dan praktis serta nilainya sama dengan emas yang pernah dijadikan sebagai patokan pada masa dulu. Sekarang ini emas tidak bisa langsung digunakan untuk mengurus urusan administrasi perkawinan, sehingga pembayaran dengan uang jauh lebih efektif dan mudah untuk dimanfaatkan.

Kewajiban pembayaran rompak paga bagi para lelaki pendatang di luhak ini memiliki tujuan tertentu. Pada dasarnya tujuan-tujuan pembayaran ini terlihat tidak sama antara satu nagari dengan nagari yang lain. Ada ninik mamak nagari yang mengatakan bahwa tujuan pembayaran rompak paga adalah untuk kepentingan

\footnotetext{
50 Datuak Tuluh, Niniak Mamak suku Jambak di Sungai Durian, wawancara, (29 Juli 2017).

51 Dalam tiap nagari di Luhak Lima Puluh Kota ada empat kelompok komunitas matrilineal dengan nama Kaampek Suku. Di Nagari Sungai Durian Kaampek Sukunya adalah (1) Suku Sambilan yang di dalamnya ada 9 suku dengan 9 ninik mamak (kepala suku). (2) Suku Ompek Niniak yang di dalamnya ada 4 suku dengan 4 ninik mamak. (3) Suku Ompek Umpuak yang di dalamnya ada 4 suku dengan empat ninik mamak dan (4) Bodi Nan Onam yang di dalamnya ada 6 suku dengan 6 ninik mamak. Keempat komunitas matrilineal ini mempunyai gelar kebesaran sesuai dengan fungsinya masing-masing yaitu Rajo Adat untuk Suku Sambilan, Pamuncak Adat untuk Ompek Niniak, Rajo Ibadat untuk Ompek Umpuak dan Peti Bunian Adat untuk Bodi Nan Onam. Yuhar Datuak Gindo Rajo Nan Sati, Ninik Mamak Suku Picancang Suku Sambilan, wawancara, (Lamposi, 12 Agustus 2017).
} 
adat di nagari tersebut. Uang rompak paga diserahkan kepada peti bunian (pemuka adat yang bertugas dan berwenang mengurus urusan uang dan administrasi adat) yang ada di tiap nagari52 dan digunakan untuk memperbaiki balai adat serta masjid. Di nagari-nagari lain, uang rompak paga diperutukkan tidak hanya untuk kepentingan adat semata tetapi juga diberikan kepada pribadi ninik mamak atas nama jabatannya sebagai penghulu untuk mengurus urusan perkawinan kemenakan perempuannya. Di Nagari Durian Godang bayaran rompak paga senilai 1.5 mas (sekitar Rp. 1.600.000,-) dibagi dua antara kepentingan adat dan untuk pribadi ninik mamak. ${ }^{53}$ Khusus di Nagari Batu Bolang, jika banyak ninik mamak yang hadir dalam musyawarah manaiak an siriah (istilah untuk lamaran/pertunangan) dalam rangka membicarakan pelaksanaan perkawinan kemenakan mereka, maka semakin banyak biaya rompak paga yang harus dikeluarkan untuk ninik mamak tersebut oleh calon mempelai lakilaki. ${ }^{54}$

Di nagari tertentu, peruntukan ini diatur secara jelas dan di nagari lain sesuai dengan kesepakatan antara ninik mamak saja. Di Nagari Sungai Baringin misalnya, ninik mamak yang bersangkutan mendapat bagian Rp.200.000,- (dua ratus ribu rupiah), Tuanku adat 2 (dua) orang Rp. 40.000,- (empat puluh ribu rupiah), kas Kerapatan Adat Nagari (KAN) Rp.80.000,- (delapan puluh ribu rupiah), Pucuk Adat Nagari (PAN) Rp.50.000,- (lima puluh ribu rupiah), pembangunan masjid Rp.80.000,- (delapan puluh ribu rupiah), pegawai adat 2 (dua) orang Rp.50.000,- (lima puluh ribu rupiah), dan pengurusan administrasi calon pengantin perempuan Rp.250.000,(dua ratus lima puluh ribu rupiah). ${ }^{55}$ Di wilayah Tujuah Koto dan Balai Talang dibagi dua antara ninik mamak dan kas nagari. ${ }^{56}$ Dalam peraturan nagari dicantumkan jumlah bayaran rompak paga sebanyak

52 Maizar Datuak Nadi, Niniak Mamak Suku Caniago Nagari Lamposi (Peti Bunian Adat), wawancara, (13 Agustus 2017).

53 Datuak Ghambai, Niniak Mamak suku di Nagari Durian Godang, wawancara, (23 Juli 2017).

54 Herisman Datuak Damuanso Nan Itam, Niniak Mamak Suku Melayu Madailiang, wawancara, (Batu Bolang, 30 Juni 2017).

55 Peraturan Adat Salingka Nagari Di Lingkungan Kerapatan Adat Nagari (KAN) Kenagarian Sungai Baringin Kecamatan Payakumbuh Kabupaten Lima Puluh Kota Pasal 6

56 H.Muklis Datuak Rajo Mangkuto Panjang Lidah, wawancara, (Balai Talang, 6 Agustus 2017) 
Rp.200.000,- tetapi dalam wawancara dengan beberapa ninik mamak ditemukan jika jumlahnya kadang-kadang lebih banyak dari yang dicantumkan dalam peraturan nagari.

Pada satu sisi, pola ini seolah-olah menggambarkan keadaan yang kurang baik yaitu adanya pungutan-pungutan tak resmi pada pendatang laki-laki di wilayah Luhak Lima Puluh Kota. Hanya saja pungutan-pungutan ini tidak sepenuhnya bernilai negatif. Sekalipun ninik mamak mendapatkan bagian dari bayaran rompak paga, tetapi uang itu umumnya digunakan untuk mengurus urusan perkawinan kemenakan perempuannya mulai dari biaya perjalanan pengurusan, akomodasi, foto copy surat-menyurat dan lain-lain. Menurut beberapa ninik mamak di Luhak Lima Puluh Kota, keberadaan mereka sebagai kepala suku (mamak penghulu) semestinya disertai/didampingi oleh harta pusaka yang produktif untuk melancarkan-urusan-urusan adat. Akan tetapi, harta pusaka ini semakin lama semakin habis dan gelar kepala suku masih tetap ada serta kewajiban-kewajiban yang melekat padanya dan kewajibankewajiban itu memerlukan dukungan biaya dalam pelaksanaannya. Oleh karena itu, tradisi bayaran rompak paga menjadi satu alternatif yang membantu kemudahan pelaksanaan tugas-tugas pemuka adat. Artinya, ninik mamak mengambil/menerima bayaran rompak paga atas nama dirinya tetapi diperuntukkan untuk urusan adat yang diembannya.

\section{Akibat Hukum Keengganan Pembayaran Rompak Paga}

Pada dasarnya daya paksa satu aturan terletak pada ancaman hukuman yang dicantumkan pada peraturan itu dan kemauan pihak berwenang untuk melaksanakan ancaman tersebut. Hal yang sama juga berlaku dalam aturan adat dan hukumnya. Setiap aturan adat yang dibuat dan dilaksanakan secara terus-menerus oleh masyarakat biasanya memiliki daya paksa yang termaktub dalam ancaman hukumannya. Kadang-kadang ancaman dan hukuman yang ada dalam masyarakat adat tertentu lebih berat dari aturan perundangan yang dikeluarkan oleh negara sekalipun tidak dalam bentuk tertulis.

Oleh karena itu, ketaatan dan kepatuhan terhadap peraturan adat terlihat lebih tinggi di tengah masyarakat. Di antara indikator tingginya ketaatan dan kepatuhan terhadap aturan adat adalah informasi nagari tentang rendahnya pelanggaran-pelanggaran adat di 
nagari-nagari ini dibanding pelanggaran-pelanggaran aturan hukum/negara. Para ninik mamak memiliki peran penting dan strategis dalam menjaga dan memelihara anak kemenakan mereka masing-masing di antaranya dengan menerapkan peraturanperaturan adat ini. Utamanya pemahaman menyangkut hukuman/sanksi adat yang berat ketika dilanggar.

Dalam adat Minangkabau termasuk adat dalam lingkungan Luhak Lima Puluh Kota dikenal hukuman dibuang sepanjang adat. ${ }^{57}$ Hukuman ini menjadi hukuman utama dalam berbagai jenis pelanggaran adat di Sumatera Barat termasuk di Luhak Lima Puluh Kota. Hukuman dibuang sepanjang adat ini juga diterapkan pada orang yang enggan membayar biaya rompak paga yang telah ditetapkan oleh kerapatan adat. Nagari-nagari di lingkungan Luhak Lima Puluh Kota menyebut hukuman buang ini dengan ungkapan adat yang berbedabeda.

Misalnya Nagari Batu Bolang menyebutnya dengan istilah ditulak abih dari kampuang,58 Nagari Sungai Baringin menyebutnya dengan ungkapan indak dipanggia dalam pemakaian adat,59 Nagari Lamposi menyebut hukuman ini dengan ungkapan indak dibao soto dalam adat.60 Selain hukuman dibuang sepanjang adat, kepada calon (suami) dari luar nagari dan pada keluarga pasangannya yang enggan patuh ini diberikan hukuman moral lainnya seperti dicela dan dicap sebagai orang yang tidak memiliki sopan santun sebagai pendatang baru, egois dan tidak pandai menghargai orang lain. Tidak cukup sampai di situ, biasanya ninik mamak memperbincangkan hal ini

57 Ahli hukum adat Belanda Ter Haar pernah mengatakan bahwa is dan zijn besliissing: dit optreden va het volkshoofd is geoorloofd, dan kristalliseert in en door zijn beslissing de regei van adat recht, die dewederrrechtelijkheid opheft (adapun tindakan atau keputusan wali nagari/ninik mamak/kepala desa tersebut adalah sah, karena telah sesuai dengan ketentuan dalam hukum adat, yang karenanya keputusan tersebut memiliki/menimbulkan kekuatan hukum langsung) terhadap keputusan Raad van Justitie Padang tanggal 3 Desember 1936 yang memutuskan hukuman dibuang sepanjang adat kepada seorang laki-laki dan seorang perempuan Minang yang kawin lari. Lihat Chairul Anwar, Hukum..., 150.

58 Efrizal Datuak Rajo Penghulu Nan Gomuak, Niniak Mamak Suku Bodi Sipanjang, wawancara, (Batu Bolang, 31 Juli 2017).

59 Peraturan Adat Salingka Nagari Di Lingkungan Kerapatan Adat Nagari (KAN) Kenagarian Sungai Baringin Kecamatan Payakumbuh Kabupaten Lima Puluh Kota

60 Datuak Damuanso, Ninik Mamak Suku Jambak Nagari Parambahan, wawancara, (29 Juli 2017). 
dalam Kerapatan Adat Nagari (KAN) dan KAN sebagai pemegang keputusan tertinggi adat merekomendasikan kepada ninik mamak sukunya agar rompak paga ini ditunaikan.

Bentuk pengabaian secara adat terhadap orang (keluarga) yang enggan membayar biaya rompak paga terlihat berbeda di setiap wilayah nagari. Misalnya tidak diundang dalam kegiatan-kegiatan adat seperti pesta perkawinan (dalam bahasa Minang disebut dengan baralek), sunatan, dan khatam al-Qur`an di wilayah nagari.

Berdasarkan isi pasal dalam peraturan nagari dan wawancara dengan ninik mamak di atas diketahui bahwa hukuman buang sepanjang adat atas keengganan membayar biaya rompak paga memang masih diberlakukan di nagari-nagari Luhak Lima Puluh Kota. Bahkan hukuman adat itu "merembet" pada masalah-masalah lain di luar adat seperti yang tercantum dalam peraturan nagari. Hal ini bisa dipahami karena tradisi rompak paga telah dilegalisasi pemerintah daerah dalam peraturan nagari. Selain itu, alasan ninik mamak suku/nagari memberikan hukuman dibuang sepanjang adat kepada kemenakannya (keluarga adik/kakak perempuannya) diperkuat oleh negara dengan dikeluarkannya Surat Edaran Kantor Wilayah Kementerian Agama Provinsi Sumatera Barat Nomor Kw.03/5/Pw.01/615/2016 tentang Antisipasi Gerakan LGBT (Lesbian Gay Biseksual dan Transgender) yang mengatur penglibatan ninik mamak dalam memastikan jenis kelamin kemenakannya dalam satu surat pernyataan. ${ }^{61}$

\section{Nilai-nilai 'Urf yang Terkandung dalam Tradisi Rompak Paga}

Secara faktual, nilai-nilai matrilineal Minangkabau memang telah mengalami perubahan di berbagai sisi tetapi secara substansi perubahan itu tidak mengikis habis nilai-nilai matriarchat Minangkabau itu sendiri. Di setiap sudut nagari Minangkabau masih terjaga berbagai ragam adat Minangkabau yang mencerminkan nilainilai keutuhan kekerabatan matrilineal baik dalam perkawinan maupun aktifitas adat lainnya. Nilai-nilai itu terus berkembang dan disemarakkan kembali dalam berbagai bentuk. Upara

61 Dokumen Kantor Urusan Agama (KUA) tentang Edaran Kantor Kementerian Agama Kabupaten Lima Puluh Kota Tentang Antisipasi Gerakan LGBT di Sumatera Barat poin 1 yang berbunyi "diketahui mamak kaum yang bersangkutan." 
menyemarakkan nilai-nilai adat di antaranya ditemukan dalam tradisi rompak paga di Luhak Lima Puluh Kota. Dalam hal ini, secara internal kekuasaan mamak kaum/suku ditunjukkan pada laki-laki pendatang (calon suami) sebagai pemberitahuan bahwa dia (mereka) masih terikat, menjaga dan memelihara kemenakan perempuannya. Di antara bentuk jagaan itu adalah dengan turun tangan membantu kemudahan pengurusan administrasi dan penyelenggaraan perkawinannya. Di antara biayanya diperoleh dari bayaran rompak paga. Secara eksternal, dengan kekuasaannya mamak penghulu memberitahukan kepada masyarakat nagari tentang anggota atau pendatang baru yang memasuki sukunya.

Pada sisi lain, komunitas masyarakat Minangkabau sebagai extended family hidup dengan tatanan sosial yang tinggi. Kesopanan dan kesantunan pendatang baru dari luar suku/nagari/luhak diperlukan untuk menjaga dan memelihara hubungan baik antara ninik mamak suku dengan kemenakannya. Seorang pendatang baru perlu untuk menunjukkan penghargaan terhadap adat orang lain dengan ungkapan/pepatah dima bumi dipijak di situ langik dijunjuang dengan makna di mana saja seseorang berada, dia harus patuh pada aturan yang berlaku di wilayah tersebut. Secara logika, dimanapun seseorang berada, maka sudah sewajarnya dia mengetahui, memahami dan melaksanakan semua aturan yang berlaku di wilayah tersebut. Pola ini mengukuhkan identitasnya sebagai lelaki pendatang dalam komunitas matrilineal keluarga calon isterinya. Sehingga kedatangannya disambut baik dan diterima secara terbuka. Penerimaan masyarakat secara terbuka pada pembayaran rompak paga ini menjadi alasan yang kuat bagi ninik mamak suku untuk memeliharanya menjadi sebuah adat dan kebudayaan lokal yang berkelanjutan.

'Urf sebagai dalil hukum memainkan peranan penting dalam pengembangan Islam di nusantara yang sarat dengan khazanah budaya. Di sisi lain, 'urf bisa menjadi peredam orang-orang yang anti pada tradisi lokal.62 Tradisi rompak paga sudah ada sejak lama dan ninik mamak tidak mengetahui kapan tradisi itu dimulai karena saat ini mereka hanya mendapati dan menjalankan apa yang sudah ada

${ }^{62}$ Ach. Maimun, "Memperkuat 'Urf dalam Pengembangan Hukum Islam," al-Ihkam, Vol. 12, No. 1, (Juni 2017), 23 
dan mereka terima secara turun-temurun. Dalam konsep 'urf, kebiasaan turun-temurun dan terus berlangsung sampai hari ini bisa menjadi salah satu alasan untuk menetapkan hukum bahwa perbuatan itu boleh untuk terus dilakukan. Di samping itu, masyarakat secara umum mematuhinya sekalipun ada beberapa (jumlah yang sangat kecil) yang tidak mematuhinya dengan alasan ekonomi yang tidak memadai. Dalam beberapa kasus yang ditemui, ketika calon mempelai laki-laki dari luar Luhak Lima Puluh Kota tidak memiliki uang yang cukup untuk membayar biaya rompak paga, maka biayanya dibayar sendiri oleh keluarga perempuan atau ninik mamak yang bersangkutan dengan tujuan untuk menjaga harga diri keluarga perempuan utamanya ninik mamak di hadapan adat.

Pada dasarnya pelaksanaan rompak paga ini tidak berseberangan dengan prinsip-prinsip syari'at Islam sekalipun hal ini tidak diatur secara jelas dalam al-Qur'an dan Sunnah. Pelaksanaan pembayaran rompak paga memiliki nilai kemaslahatan (kebaikan) seperti menjalin dan mengukuhkan kembali hubungan silaturrahim antar anggota kerabat suku (ibu, saudara lelaki, kemenakan). Menjalin hubungan silaturrahim adalah suatu keharusan dalam Islam dan orang-orang yang memutuskan hubungan silaturrahim di antara mereka dipandang bercela dan dapat mempengaruhi nilai-nilai transenden (ibadah) mereka kepada Tuhan.

\section{Penutup}

Adat dan budaya satu kelompok masyarakat senantiasa mengalami perubahan seiring dengan perubahan pada diri masyarakat itu sendiri. Perubahan itu terjadi di banyak sisi tetapi belum mengubah substansi matrilineal yang selama ini banyak diprediksi. Bagi masyarakat Minang yang pergi merantau, perubahan itu mungkin saja terjadi karena jarak antara rantau dengan tanah asalnya sangat jauh dan ada kesukaran tersendiri dalam memelihara adat di wilayah perantauan tetapi perubahan itu tidak terlihat jelas pada para perantau urban.

Perubahan substantif tidak sepenuhnya terjadi di tanah Minangkabau. Masyarakat di setiap luhak (Tanah Datar, Agam dan juga Luhak Lima Puluh Kota) masih terikat dengan kuatnya hubungan kekerabatan antara ibu, anak-anaknya serta saudara lelaki ibu (mamak). Hal ini dapat dilihat dalam adat perkawinan yang 
menampakkan eksistensi kewenangan mamak terhadap kemenakannya. Di antara kewenangan itu adalah keharusan membayar uang adat rompak paga atau uang atas nama adat bagi seorang laki-laki luar nagari atau luar luhak jika ingin menikah dengan kemenakannya yang ada di Luhak Lima Puluh Kota. Meskipun secara nominal jumlah uang adat rompak paga yang diminta tidak terlalu berat (min. Rp.100.000,- mak. Rp.1.600.000,-) tetapi akibat pengabaiannya memberi akibat yang berat secara adat dan akibat itu tidak hanya ditanggung secara pribadi oleh keluarga tetapi ditanggung juga oleh ninik mamak di hadapan adat. Oleh karena itu, nilai kepatuhan membayar sedikit/kecilnya biaya rompak paga menunjukkan besarnya kewenangan adat (ninik mamak) terhadap kemenakan perempuannya.

Dalam hukum Islam, setiap orang dikenali berdasarkan identitas keagamaan yang dimilikinya. Sementara itu dalam adat Luhak Lima Puluh Kota dan Minangkabau umumnya, identitas masyarakat adalah adatnya dan adatnya itu adalah peraturan hidup sehari-hari yang sudah berlangsung lama dan tetap terpelihara sampai hari ini. Bagi masyarakat Luhak Lima Puluh Kota, ketika hidup tanpa mematuhi aturan artinya tidak beradat. Padahal adat itu yang menjadi pakaiannya sehari-hari yaitu adat basandi syarak, syarak basandi Kitabullah (adat sendi (dasar)nya adalah syarak (syari'at Islam) dan syarak dasarnya adalah al-Qur`an). Oleh karena itu, rompak paga sebagai adat sudah menjadi pakaian sehari-hari masyarakat Luhak Lima Puluh Kota karena nilai yang dikandung pelaksanaan adat rompak paga ini tidak hanya sekedar pengukuhan identitas lelaki pendatang dalam komunitas suku isterinya tetapi menampakkan kekuasaan/kewenangan mamak dalam menjaga eksistensi adat umumnya dan menjaga kemenakan serta hubungan silaturrahim dalam keluarga besarnya.

\section{Daftar Pustaka}

Artikel

Azmi, Ulfa Ufi, “Tinjauan Hukum Islam Terhadap Praktik Pisuka Pada Perkawinan Adat Masyarakat Muslim Suku Sasak Di Kelurahan Ampenan Tengah Lombok Barat, Thesis, UIN Sunan Kalijaga, 2012. 
Chuzaifah, Yuniyanti, "Dekonstruksi Makna Kuasa dalam Matriarchy", Studia Islamika, Vol. 9, Nomor 2, 2002.

Evers, Hans Dieter, "Changing Patterns of Minangkabau Urban LandOwnership", Bijdragen tot de Taal, Vol. 131, Nomor 1, 1975.

Ilman, Muhammad, "Tradisi Pembayaran Uang Pelangkah dalam Perkawinan (Studi Kasus di Desa Legok, Kecamatan Legok Kabupaten Tangerang," Skripsi, UIN Jakarta, 2016.

Iqbal, Moh., "Tinjauan Hukum Islam Tentang Uang Panaik (Uang Belanja) Dalam Perkawinan Adat Suku Bugis Makassar Kelurahan Untia Kecamatan Biringkanaya Kota Makassar," Thesis, UIN Sunan Ampel Surabaya, 2012.

Kahn, J.S., "Tradition", Matriliny and Change among the Minangkabau of Indonesia", Bijdragen tot de Taal, Vol. 132, No. 1, 1976.

Maimun, Ach, "Memperkuat 'Urf dalam Pengembangan Hukum Islam," al-Ihkam, Vol. 12, No. 1, 2017.

Nur, Sri Susyanti dan Abrar Saleng, "Aspek Sosioyuridis Lahan Budidaya Rumput Laut Sebagai Mahar Perkawinan di Kabupaten Bantaeng Sulawesi Selatan," Prosiding Akuakultur Indonesia, 2013.

Pardosi, Jhonson, "Makna Simbolik Umpasa, Sinamot dan Ulos Pada Adat Perkawinan Batak Toba," Logat Jurnal Ilmiah Bahasa dan Sastra, Volume IV, Nomor 2, Oktober 2008.

Sugianto, Bambang, "Kualitas dan Kuantitas Mahar dalam Perkawinan (Kasus Wanita yang Menyerahkan Diri kepada Nabi SAW," Asy-Syir'ah Jurnal Ilmu Syari'ah dan Hukum, Volume 45, Nomor II, Juli-Desember 2011.

Tanner, Nancy Makepiece, "The Nuclear Family in Minangkabau Matriliny: The Mirror of Disputes", Bijdragen tot de Taal, Vol. 138, Nomor 1, 1982.

Wekke, Ismail Suardi, "Islam dan Adat dalam Pernikahan Masyarakat Bugis di Papua Barat," Thaqafiyyat, Volume 13, Nomor 2, Desember 2012.

Yelepele dan Moh. Hefni, "Perkawinan Adat Muslim Suku Dani di Papua, al-Ihkam, Vol. 7, No.1, 2012.

\section{Dokumen}


Berita Acara Rapat Koordinasi antara Pemerintahan Nagari dengan Kerapatan Adat Nagari (KAN) Nagari Batu Balang Tanggal 03 Februari 2015.

Dokumen Kantor Urusan Agama (KUA) tentang Edaran Kantor Kementerian Agama Kabupaten Lima Puluh Kota Tentang Antisipasi Gerakan LGBT di Sumatera Barat.

Peraturan Adat Salingka Nagari Di Lingkungan Kerapatan Adat Nagari (KAN) Kenagarian Sungai Baringin Kecamatan Payakumbuh Kabupaten Lima Puluh Kota.

Peraturan Nagari Durian Gadang Nomor 04 Tahun 2009 Tentang Pungutan Nagari.

Perubahan Peraturan Nagari Guguak VII Koto Talago Nomor 3 Tahun 2015 Tentang Iuaran Jasa Pelayanan Administrasi.

\section{Buku}

Amran, Rusli, Sumatera Barat Hingga Plakat Panjang, Jakarta: Sinar Harapan, 1985.

Anwar, Chairul, Hukum Adat Indonesia Meninjau Hukum Adat Minangkabau, Jakarta: Rineka Cipta, 1997.

Badan Pusat Statistik, Kabupaten Lima Puluh Kota Dalam Angka Tahun 2016.

Badan Pusat Statistik, Payakumbuh Dalam Angka, Payakumbuh: BPS Kota Payakumbuh, 2015.

Departemen Pendidikan Nasional, Kamus Besar Bahasa Indonesia, Jakarta: Gramedia, 2011.

Jeffrey Hadler, Sengketa Tiada Putus: Matriarkat, Reformisme Islam, dan Kolonialisme di Minangkabau, Judul asli: Muslim and Matriarchs: Cultural Resilience in Indonesia Through Jihad and Colonialism, Penerjemah, Samsudin Berlian, Jakarta: Freedom Institute, 2010.

Hasabullah, Ali, Ushûl al-Tasyrî̀' al-Islâmî, Mesir: Dar al-Ma'arif, 1971.

al-Jawziyyah, Ibnu Qayyim, I'lâm al-Muwaqi'în, Jilid II, Kairo: Dâr al‘Urûbah, 1998.

al-Kasânî, Ibnu Mas'ûd, Badâi' al-Shanâi' fi Tartîb al-Syarâi', Jilid II, Beirât: Dâr al-Fikr, 2008.

M.S., Amir, Adat Minangkabau Pola dan Tujuan Hidup Orang Minang, Jakarta: Mutiara Sumber Widya, 2003. 
Naim, Mochtar, Merantau Pola Migrasi Suku Minangkabau, Jakarta: Rajawali Pers, 2013.

Nasroen, M, Dasar Falsafah Adat Minangkabau, Jakarta: Pasaman, 1957.

Panuh, Helmy, Pengelolaan Tanah Ulayat Nagari pada Era Desentralisasi Pemerintahan di Sumatera Barat, Jakarta: Rajawali Pers, 2012.

Qudâmah, Ibnu, al-Mughnî, Beirût: Dâr al-Fikr, 2011.

Sarakhsî al-. Kitâb al-Mabsûth, Beirût: Dâr al-Fikr, 1999.

Shan'ânî, Muhammad ibn Ismâ'il al-Kahlanî al-. Subul al-Salâm, Beirût: Dâr al-Fikr, 2004.

Suyûthî al-. al-Asybâh wa al-Nazhâir. Beirût: Dâr al-Fikr, 1989.

Syarbinî, Muhammad Khatîb al-. Mughnî al-Muhtâj. Jilid III, Beirût: Dâr al- Fikr, 1997.

Syarifuddin, Amir, Pelaksanaan Hukum Kewarisan Islam dalam Lingkungan Adat Minangkabau, Jakarta: Gunung Agung, 1984.

Syâthibî al-. al-I'tishâm. Beirût: Dâr al-Fikr, 2007.

Syawkânî al-. Nayl al-Awthâr, Kairo: Dar al-Hadis, 2010.

Syirazî, al-Fayruzzabadî al-. al-Muhazzab, Beirût: Muassasah alRisâlah, 1989.

Taufiq, Sutan M, (red.), Direktori Minangkabau 2012, Batusangkar: Badan Pekerja Pucuak Adat Alam Minangkabau (BP-PAAM) Istano Silinduang Bulan Pagaruyuang-Batusangkar dan Lembaga Kerapatan Adat Alam Minangkabau (LKAAM) Provinsi Sumatera Barat

Zahrah, Abu, al-Ahwâl al-Syakhshiyyah. Beirût: Dâr al-Fikr, 2009.

Zaydan, Abd al-Karim, al-Wajîz fi Ushûl al-Fiqh. Beirût: Muassasah alRisâlah, 2009.

Zuhaylî, Wahbah al-. Ushûl al-Fiqh al-Islâmî, Beirût: Dâr al-Fikr, 1986. 